\title{
AUTHENTICITY TESTS OF WHITE WINES FROM THE APOLD DEPRESSION
}

\author{
Ecaterina, LENGYEL ${ }^{1}$ and László SIKOLYA ${ }^{2}$ \\ 1’Lucian Blaga" University of Sibiu, Sibiu, Romania, ecaterina.lengyel@ulbsibiu.ro \\ ${ }^{2}$ University College of Nyíregyháza, Hungary, sikolya @nyf.hu
}

\begin{abstract}
This paper aims at establishing distinctive elements regarding the authenticity of the following wines from the Apold vineyard: Sauvignon blanc, Fetească regală and Chardonnay. The paper aims at reviewing the color-giving components specific to white wines. Thus, through HPLC methods, we identified and quantified phenolic compounds which, in the end, presented total values between $86.085 \mathrm{mg} / \mathrm{L}$ and $89.272 \mathrm{mg} / \mathrm{L}$. The present study also demonstrates the authenticity of these wines through spectrophotometric methods employed to determine the color of white wines. Based on the results obtained, we established that the studied wines are authentic, as the values resulted from the calculations in the procedure range between 0.015 and 0.019 .
\end{abstract}

KEYWORDS: authenticity, white wines, phenolic compounds, HPLC, spectrophotometer

\section{INTRODUCTION}

The authenticity of a wine can be established through various procedures. Establishing the color of the wine is one such procedure. A wine's color is given especially by the concentration of phenolic compounds in it, but also by their nature. White wines are specific to the Apold Depression. Their color is given by the flavones and the hydroxycinnamic phenolic acids in the grapes. "White" wine shades present a range of colors from white, yellow-white, green-white to yellow, goldyellow, gold, green-yellow, depending on the yellow pigments given by flavones (Țârdea, 2007, Țârdea et al.2010). Phenolic compounds contribute to the formation of the sensorial traits of wines, imprinting astringent and bitter tones. Phenolic compounds in wines belong especially to derivatives of nonflavonoids, cinnamic phenolic acids, flavonoids, derivatives of volatile benzen, flavonoids such as catechin, epicatechin, anthocyanins, tanins and their derivatives (Basha et al. 2004). Compounds of non-flavonoids derive into acids such as hydroxycinnamic acid and hydroxybenzoic acid respectively, caftaric, ellagic acid or gallic acid, which are predominant in white wines (Singleton, 1992). The presence of oxygen leads to changes in the color of white wines, caused especially by the oxidation of phenolic acids, which gives them brown shades (Sims, 1994, Țârdea et al., 2010). The entire range of yellow shades comes from the colored phenolic fraction combined with non-phenolic compounds, such as proteins and polysaccharides. Colored phenolic fractions can be phenolic acids, quercetin, caftaric or caffeic acids, p-coumaric or glycosyl-coumaric acids. Hydroxycinnamic phenolic acids give color to white wines. The most abundant are: caffeic acid, p-coumaric acid, ferulic acid (Tița, 2013, Cotea, 2009). Flavones and flavonoids are the best known compounds contributing to the formation of color in white wines. The first is a derivative of flavone, i.e. 2-fenil benzopyran, while the latter is a hydroxylated derivative of flavone at $\mathrm{C} 3$. The best known flavonoid derivatives determined in white wines are: rutin, quercetin, naringin, hesperidin, kaempferol; some of them are also found in red wines (Lengyel et al. 2014). Phenolic acids present self-oxidant traits, which contributes to the protection of white wine color, especially given that they can undergo changes caused by metal ions, such as $\mathrm{Fe} 3+$ or $\mathrm{Cu} 2+$, which act as catalysts in oxidative reactions (Stegăruș et al. 2014).

\section{MATERIALS AND METHODS}

White wines (Sauvignon, Fetească regală, Chardonnay) from the Apold vineyard, production of 2014

\subsection{Determining phenolic compounds}

Smartline HPLC system KNAUER, PDA Plus Detector, Thermo Detector

Accuare PFP - Cromatography column

UV-VIS detector and fluorescence detector, serial dual piston tandem quaternary pump with contious washing of the pistons, automatic 25 microliter sample injection system, solvent degassing system, software controlling and processing the HPLC system data.

The wine samples are filtered, then they are injected into the machine; the results are expressed in $\mathrm{mg} / \mathrm{L}$ - ppm

\subsection{Determining white wine authenticity (blanc de blanc)}

In order to establish where the white wines (made exclusively from white grapes) come from, we assume that white wines made from dark grapes become light pink if treated with strong acids such as $\mathrm{HCl}$.

- $10 \mathrm{ml}$ white wine are introduced in two test tubes (A and B)

- $2 \mathrm{ml}$ distilled water are added in test tube A 


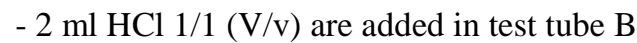

- using the spectrophotometer, we measure the optical density at a wavelength of $520 \mathrm{~nm}$ (cuvettes with a $2 \mathrm{~cm}$ optical path, DO520)

The calculation is the difference between the DOB and DOA readings; the results confirm the color authenticity if the values recorded are under or equal to 0.020 .

If the values are above or equal to 0.025 units, the wine was made from dark grapes.

\section{RESULTS AND DISCUSSIONS}

\subsection{Determining phenolic compounds}

From the results we got through the HPLC determinations, it is ascertained that the amounts of phenolic compounds in the white wines from Apold vary between $86.055 \mathrm{mg} / \mathrm{L}$ in Chardonnay wines and $89.272 \mathrm{mg} / \mathrm{L}$ in Fetească regală wines. Sauvignon wines contain $88.237 \mathrm{mg} / \mathrm{L}$ phenolic compounds. Looking at Figures 1, 3, 5 associated to the chromatograms in Figures 2, 4, 6 , we ascertain that gallic acid oscillates between $1.557 \mathrm{mg} / \mathrm{L}$ in Sauvignon wine and a maximum value of $2.982 \mathrm{mg} / \mathrm{L}$ in Fetească regală wine. The maximum amount of catechin is found in Sauvignon wines; the values recorded are $80 \%$ higher than in the case of the other two wines studied.

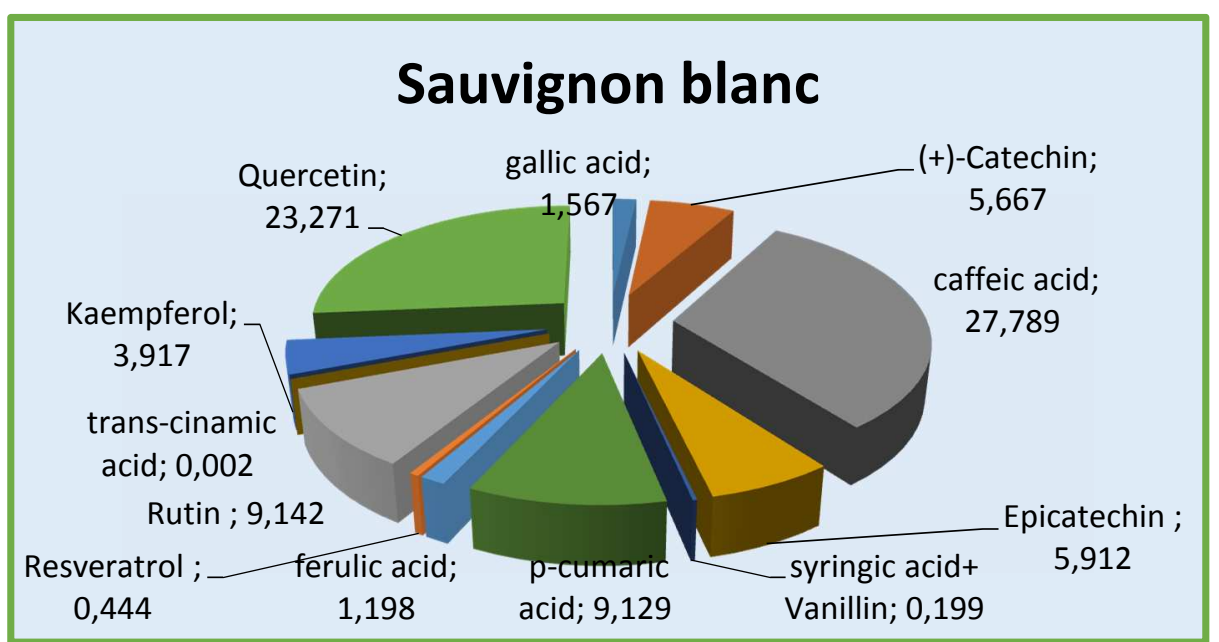

Figure 1. The accumulation of phenolic compounds expressed in $\mathrm{mg} / \mathrm{L}$ in Sauvignon blanc wines from Apold vineyard

Caffeic acid reaches $39.121 \mathrm{mg} / \mathrm{L}$ in the case of Chardonnay wine, and values lower by $23-26 \%$ in the case of Sauvignon and
Fetească wines. Epicatechin reaches $3.332 \mathrm{mg} / \mathrm{L}$ (Fetească regală), $3.921 \mathrm{mg} / \mathrm{L}$ (Chardonnay), $5.912 \mathrm{mg} / \mathrm{L}$ (Sauvignon), which are close to the values of catechin.

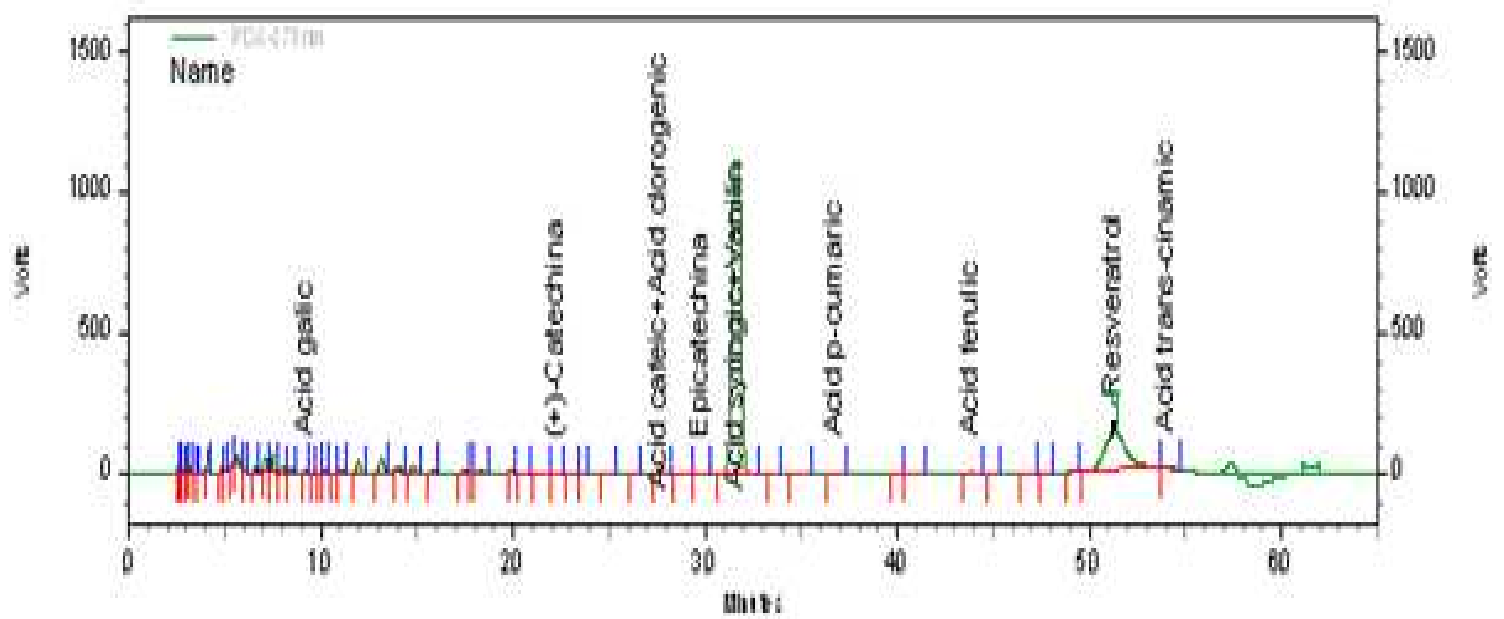

Figure 2. Chromatogram of phenolic compounds in Chardonnay wines from Apold vineyard

In all three cases, syringic acid/vanillin reaches subunitary points of about $0.2 \mathrm{mg} / \mathrm{L}$, while p-coumaric acid reaches 9.129 $\mathrm{mg} / \mathrm{L},-50 \%$ higher than in the case of Sauvignon blanc compared to Fetească regală, and $40 \%$ lower than in the case of Chardonnay. 


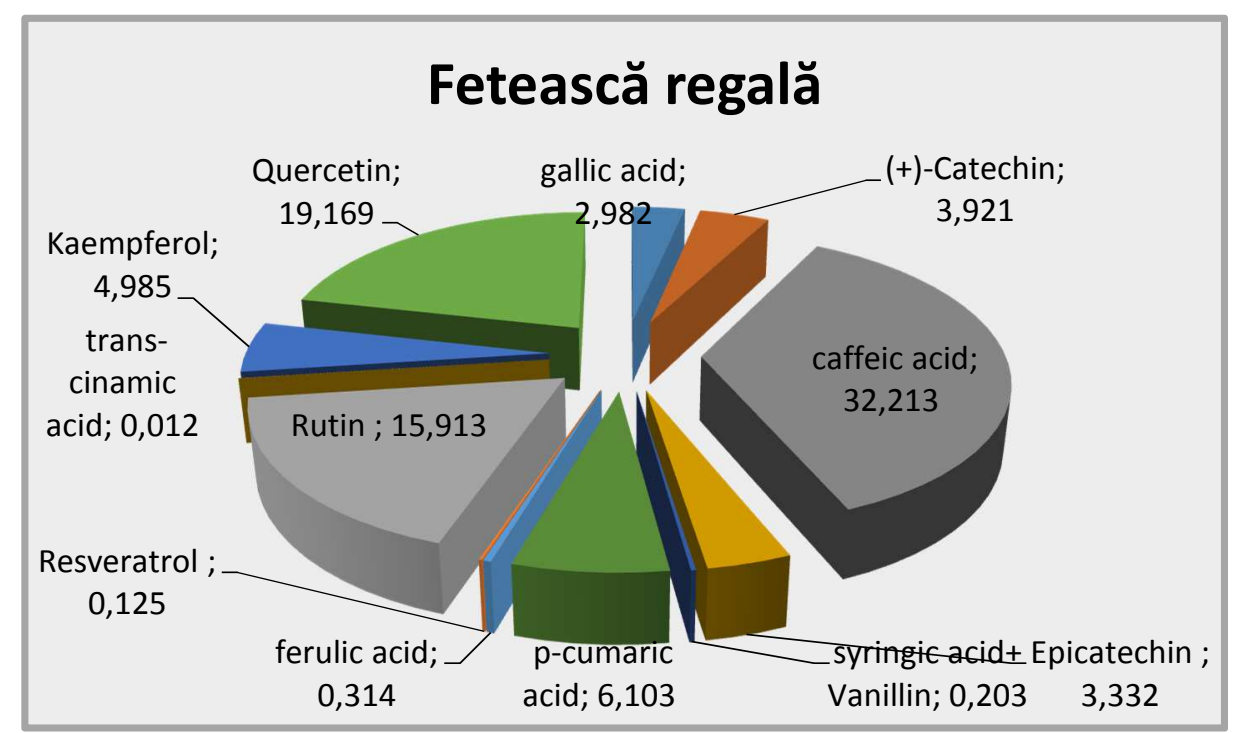

Figure 3. The accumulation of phenolic compounds expressed in mg/L in Fetească regală wines from Apold vineyard

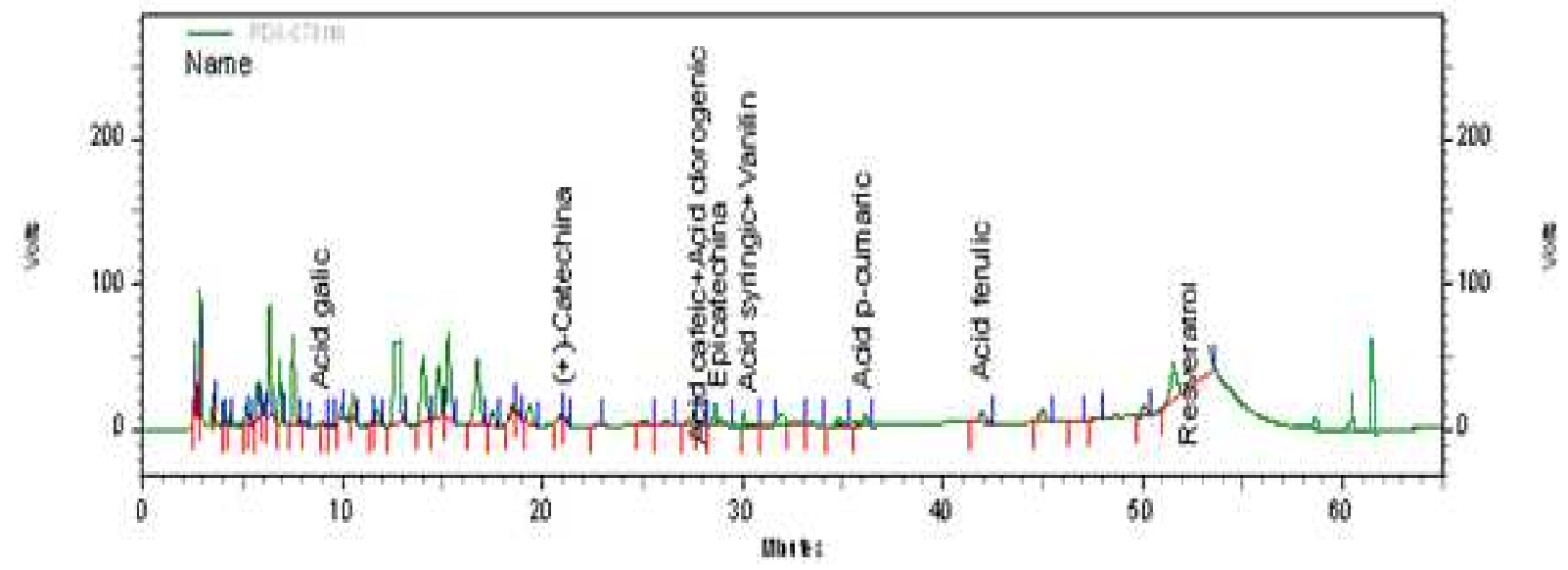

Figure 4. Chromatogram of phenolic compounds in Fetească regală wines from Apold vineyard

Another important element for wine color is ferulic acid which, in our determinations, reaches values between $0.314 \mathrm{mg} / \mathrm{L}$ (Fetească regală) and $2.120 \mathrm{mg} / \mathrm{L}$ in Charonnay wines.

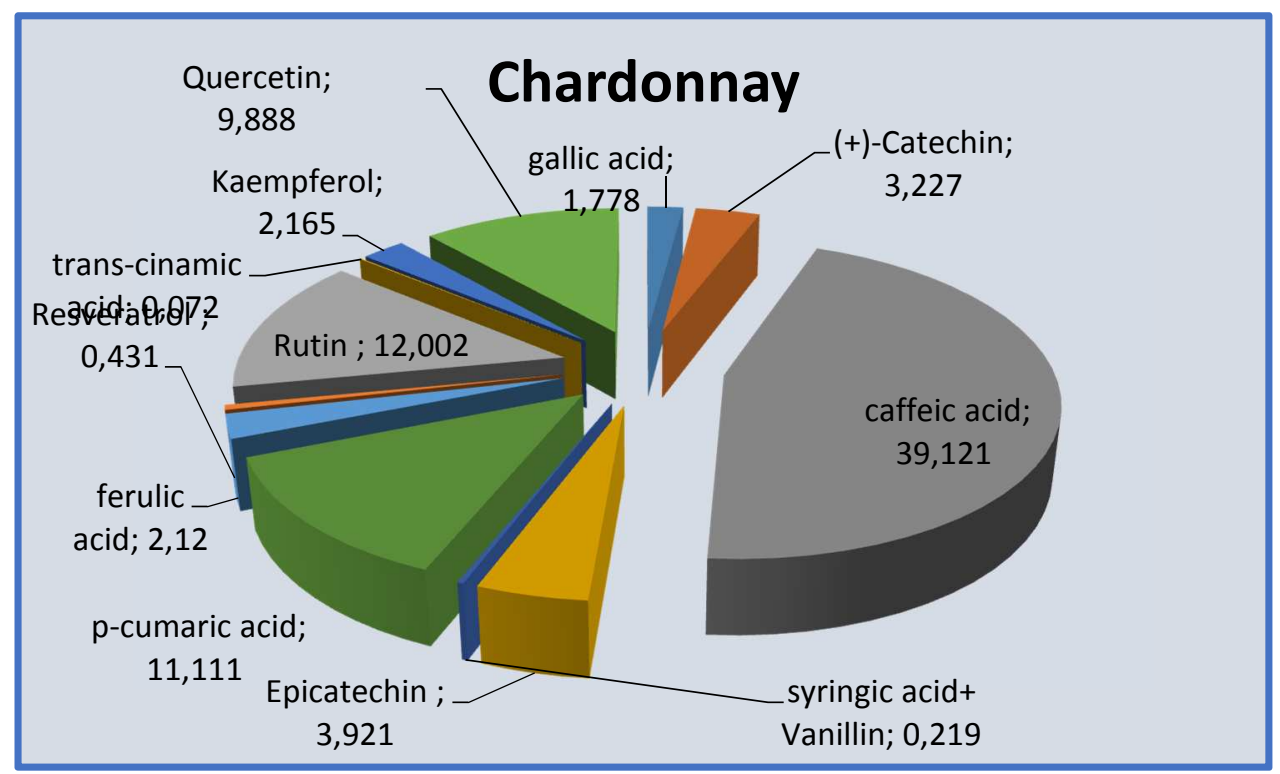

Figure 5. The accumulation of phenolic compounds expressed in $\mathrm{mg} / \mathrm{L}$ in Chardonnay wines from Apold vineyard

Less important for white wines, but specific to red wines, resveratrol does not exceed $0.450 \mathrm{mg} / \mathrm{L}$ in none of the three wines studied, while rutin reaches a minimum $9.142 \mathrm{mg} / \mathrm{L}$ (Sauvignon) and a maximum $15.913 \mathrm{mg} / \mathrm{L}$ (Fetească regală). 


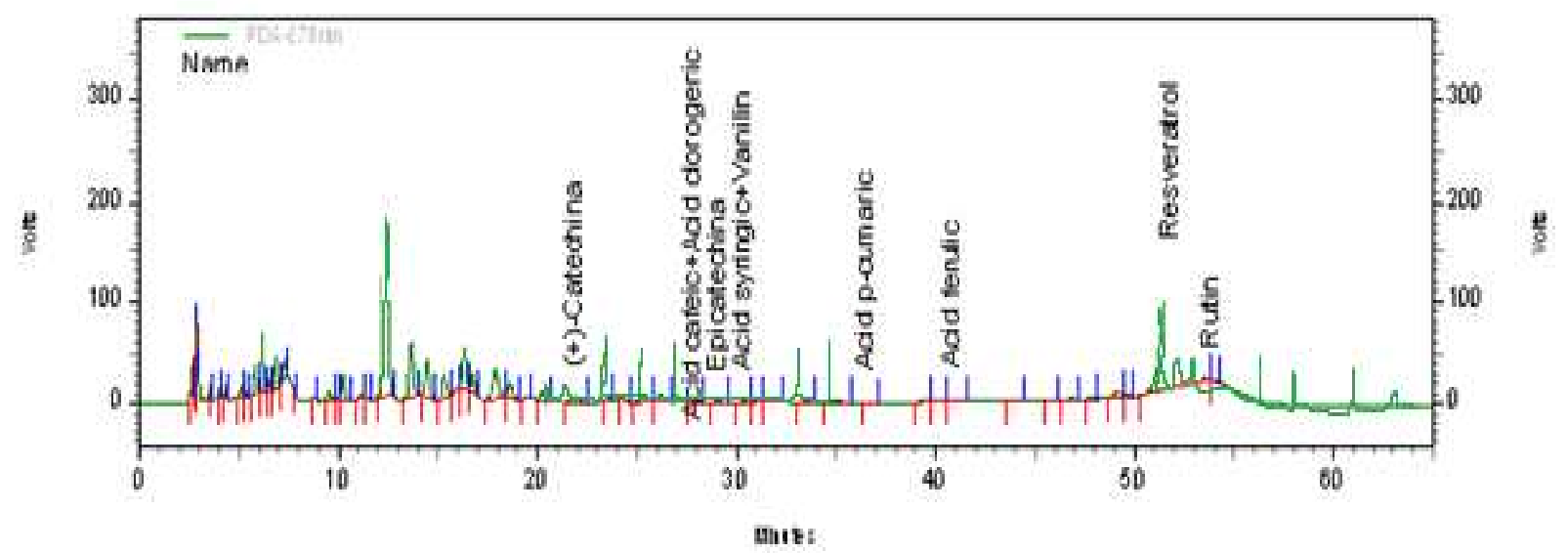

Figure 6. Chromatogram of phenolic compounds in Chardonnay wines from Apold vineyard

Trans-cinnamic acid was detected in all three wines; the values recorded were extremely low, of the order of hundreths. Thus, it was detected in Sauvignon wines, reaching $0.002 \mathrm{mg} / \mathrm{L}$, in Fetească regală reaching $0.012 \mathrm{mg} / \mathrm{L}$ and in Chardonnay 0.072 $\mathrm{mg} / \mathrm{L}$. Another compound specific to white wines, kaempferol, was detected in values between $2.165 \mathrm{mg} / \mathrm{L}$ (Chardonnay) and $4.985 \mathrm{mg} / \mathrm{L}$ (Fetească regală). Quercetin recorded values of the order of tens; the maximum value detected in Sauvignon wine was $23.271 \mathrm{mg} / \mathrm{L}$.

Determining white wine authenticity (blanc de blanc)

The readings on the Cecil 2010 spectrophotometer at wavelength $520 \mathrm{~nm}$ showed the following:

- Sauvignon Blanc wines
$\mathrm{DOB}-\mathrm{DOA}=0,174-0,159=0,015$

- Fetească regală wines

DOB - DOA $=0,193-0,174=0,019$

- Chardonnay wines

DOB - DOA $=0,188-0,172=0,016$

Figure 7 shows that the values obtained according to the calculation in the work method are under the maximum value of 0.020 , which means that the studied wines are authentic. In the case of Sauvignon wine, the difference calculated between the two readings is 0.015 . In the case of Fetească regală wine, the difference is 0.019 , while in the case of Chardonnay wine, it is 0.016 .

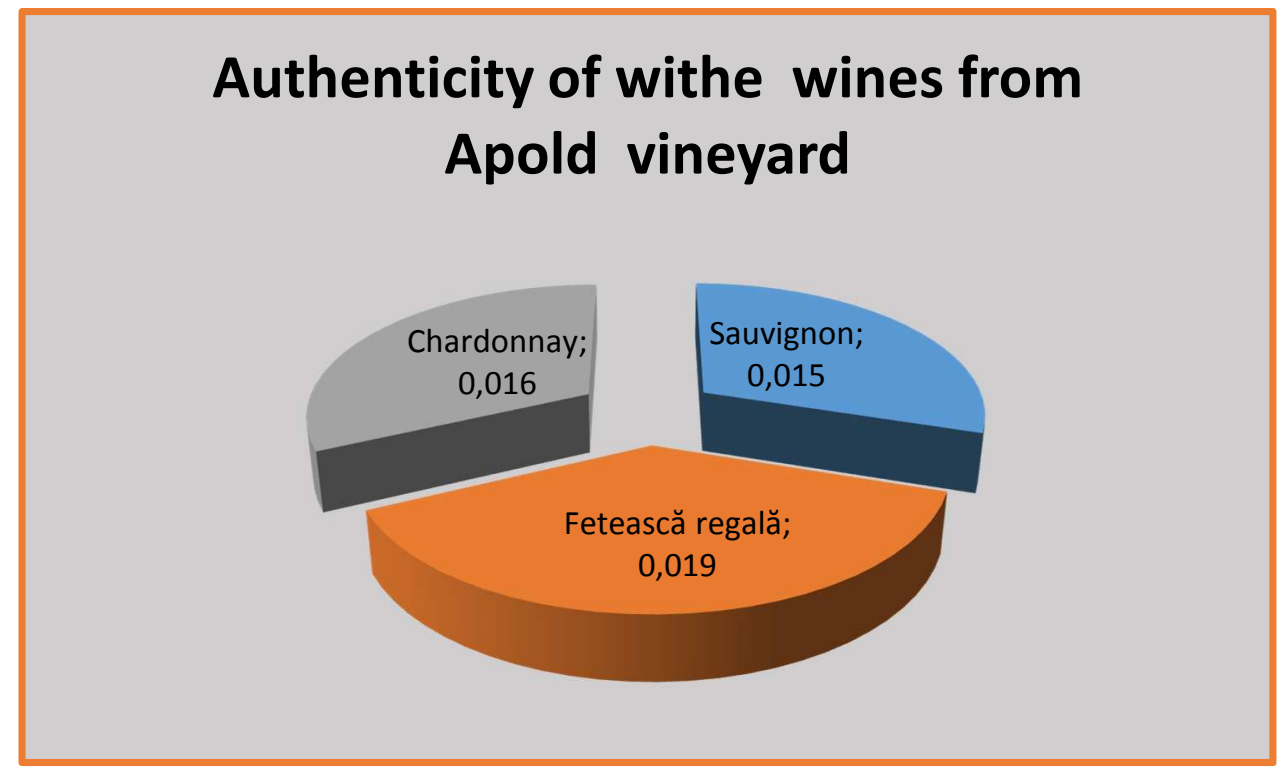

Figure 7. Spectrophotometric testing of wines from Apold vineyard to determine their authenticity

\section{CONCLUSIONS}

Phenolic compounds in the studied wines reach values which ensure their superior color and quality. A high amount of phenolic compounds may give these wines undesirable strongly astringent traits with bitter notes. The specific values obtained result in a balance between phenolic compounds; this balance is characteristic to the wines in the area, which are best quality wines. Identifying compounds such as rutin or vanillin imprint authentic notes to the wines in the area, and the fact that specific elements, such as ferulic acid, were detected in small amounts prove that the wines are young.
The results obtained from the spectrophotometric measurements and calculations made according to the procedure prove that the studied wines are authentic. Sauvignon wine presents paleyellow tones with green reflexes; Fetească regală wine is yellow-green, while Chardonnay wine is distinguished by its yellow-gold notes.

\section{ACKNOWLEDGMENT}

This work was supported by the strategic grant POSDRU/159/1.5/S/133255, Project ID 133255 (2014), cofinanced by the European Social Fund within the Sectorial Operational Program Human Resources Development 20072013 


\section{REFERENCES}

1. Basha S. M., Musingo M., Colova V. S., 2004, Compositional differences in the phenolics compounds of muscadine and bunch grape wines, African journal of biotechnology, vol 3(10), 523-528

2. Cotea D.V., Zănoagă C.V., Cotea V.V., 2009, Tratat de oenochimie, vol.I, Ed. Academiei Române Bucureşti

3. Lengyel E., Oprean L., Stegăruș D., Șandru D., Iancu R., Geană I., Mutu D., Tița O., 2014, The chromatographic detection of the rutin in the aromatic and semi aromatic autochthonous musts variety, Acta Universitatis Cibiniensis, Series E: Food Technology, ISSN 1221-4973, vol. XVIII, (1), 47-52

4. Sims C.A., 1994, Importance of control of phenols in wine, Proceedings of the ninth annual midwest regional grape and wine Conference, Osage beach, Missouri, 91-102
5. Singleton V.L. 1992, Plant polyphenols synthesis, properties and significance, Plenum press 1992, p. 859

6. Stegarus D., Niculescu V., Sandru C., Ionete R., Lengyel E, Tita O., 2014, Application of graphite furnace AAS for some transitional metals determination in romanian wines, XXXIII-rd Romanian Chemistry Conference, 1-3 october 2014, Călimănești-Căciulata, Vâlcea - România, p.24

7. Tiţa O., Lengyel E., Mutu D., Oprean L., Iancu R., Gabor D., 2013, Comparative studies regarding phenolic compounds in musts coming from Recas, aromatic, semiaromatic and red varieties, 13th International Multidisciplinary Scientific GeoConferences, SGEM Proceeding, 121-128

8. Țârdea C., 2007, Chimia și analiza vinului, Ed. Ion Ionescu de la Brad

9. Țârdea C., Sârbu G., Țârdea A., 2010, Tratat de vinificație, Ed. Ion Ionescu de la Brad 